\title{
U.S. International Transactions in 1995
}

Allan D. Brunner, of the Board's Division of International Finance, prepared this article. Virginia Carper provided research assistance.

The U.S. current account deficit widened only slightly in 1995 following three years of substantial increases. The deficit flattened over the course of the year, and it narrowed sharply in the fourth quarter, as imports of goods and services flagged while exports picked up (chart 1). The same factors underlying these developments should cause the U.S. external deficit in 1996 to remain close to its 1995 level.

Although the balance on trade in goods and services widened in 1995 , by $\$ 5$ billion, the increase was the smallest since the balance began deteriorating again in 1992 (table 1). The values of exports and imports grew rapidly and at about the same rate, but net exports fell because the initial value of imports was somewhat higher than the initial value of exports. A small trade surplus with Mexico in 1994 turned into a large deficit last year following the peso crisis and a substantial contraction in Mexican aggregate demand. The trade deficit with Canada also worsened as Canadian growth slowed markedly. In contrast, net shipments to Japan picked up significantly following a rise in the exchange value of the yen in 1994 and early last year.

In quantity terms, the rates of growth of both imports and exports of goods and services slowed

\section{U.S. external balances, 1984-95}

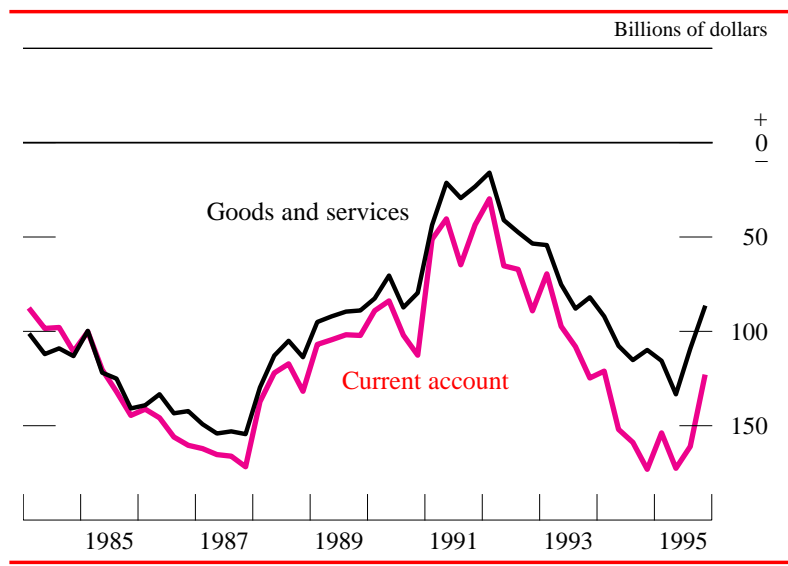

NoTE. The data are quarterly at seasonally adjusted annual rates. Current account data exclude foreign cash grants received in 1990-92.

SouRCE. U.S. Department of Commerce, Bureau of Economic Analysis, U.S. international transactions accounts.

markedly from robust rates in 1994, in line with slower economic activity in the United States and abroad. Still, export growth increased steadily throughout the year, largely in response to the strength of economic activity abroad as well as to a stabilization of exports to Mexico. In contrast, import growth sagged in the second half of the year as a result of developments in the U.S. domestic economy

1. U.S. external balances, 1990-95

Billions of dollars

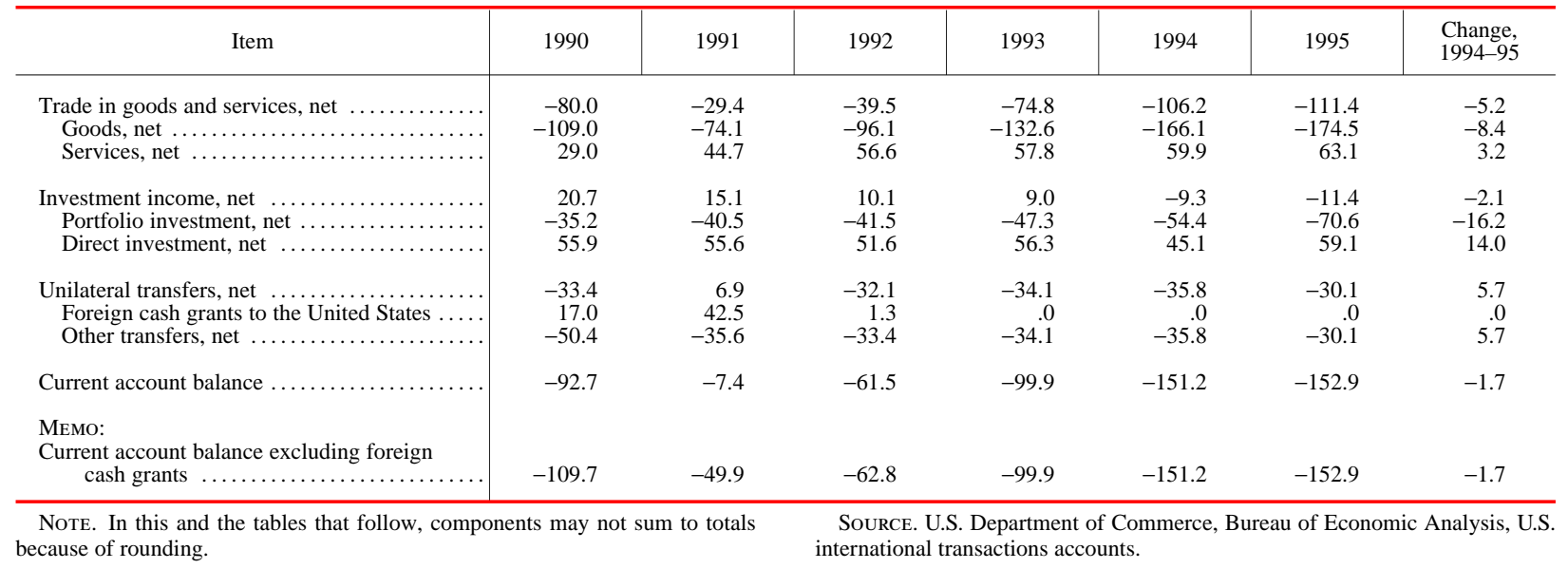


and a small increase in the relative price competitiveness of U.S. goods in domestic markets.

The balance on investment income declined about $\$ 2$ billion last year. The deterioration was due entirely to a growing deficit in net portfolio investment income, the result of a continued worsening of the U.S. net portfolio investment position and increases in interest rates in the United States in late 1994 and early 1995. In contrast, net direct investment income increased last year. Both receipts from U.S. direct investment abroad and payments on foreign direct investment in the United States increased rapidly, but the increase in receipts was larger because U.S. direct investment assets abroad are larger than foreign direct investment assets in the United States and because the rates of return reported by U.S. investors abroad were larger and increased more than the rates of return earned by foreign investors in the United States.

The current account balance was buoyed somewhat last year by a temporary $\$ 6$ billion reduction in net unilateral transfers to foreigners. Most of the reduction was due to a transient drop in government grants to foreign countries: Because of U.S. government shutdowns in late 1995, government grants that were scheduled to be disbursed in the fourth quarter were delayed until the beginning of 1996 .

Counterbalancing the continued large current account deficit in 1995 were a large recorded net inflow of capital and a large positive statistical discrepancy, which comprises some combination of unrecorded net capital flows and unrecorded net current account receipts. Much of the recorded net capital inflow was in the form of a record increase in foreign official holdings in the United States, a result of both foreign exchange intervention by certain industrialized countries and substantial reserve accumulation by several developing countries in Asia and Latin America. Private foreign assets in the United States increased sharply, but the increase was about matched by additions to private U.S. assets abroad.

\section{MAJOR ECONOMIC INFLUENCES ON U.S. INTERNATIONAL TRANSACTIONS}

The U.S. deficit in traded goods and services widened considerably between 1991 and 1995, but the increase last year was much less than in other recent years. These developments are consistent with recent movements in the two most important determinants of trade flows: relative rates of economic growth and relative price competitiveness. Although the U.S. economy in 1995 grew at about the same pace as the economies of its major trading partners, as has been true historically, the increase in U.S. income had a larger effect on expenditures on foreign goods and services than the comparable increase in foreign income had on expenditures on U.S. goods and services. This effect was offset somewhat by a small improvement in U.S. price competitiveness last year, which helped make U.S. goods and services more attractive at home relative to imports and, to a lesser extent, more attractive in foreign markets.

Financial and economic developments in Mexico in late 1994 and in 1995 also had important effects on U.S. trade. From 1991 through the third quarter of 1994, the U.S. balance on trade in goods and services with Mexico was in surplus, averaging nearly $\$ 4$ billion per year, as the Mexican economy grew somewhat faster than the U.S economy and the price of U.S. goods relative to the price of Mexican goods fell (chart 2). Following the December 1994 collapse of the peso, the trade balance deteriorated rapidly, resulting in a deficit of about \$15 billion for 1995 .

2. Historical perspective on the U.S. trade balance with Mexico and its proximate determinants, 1986-95

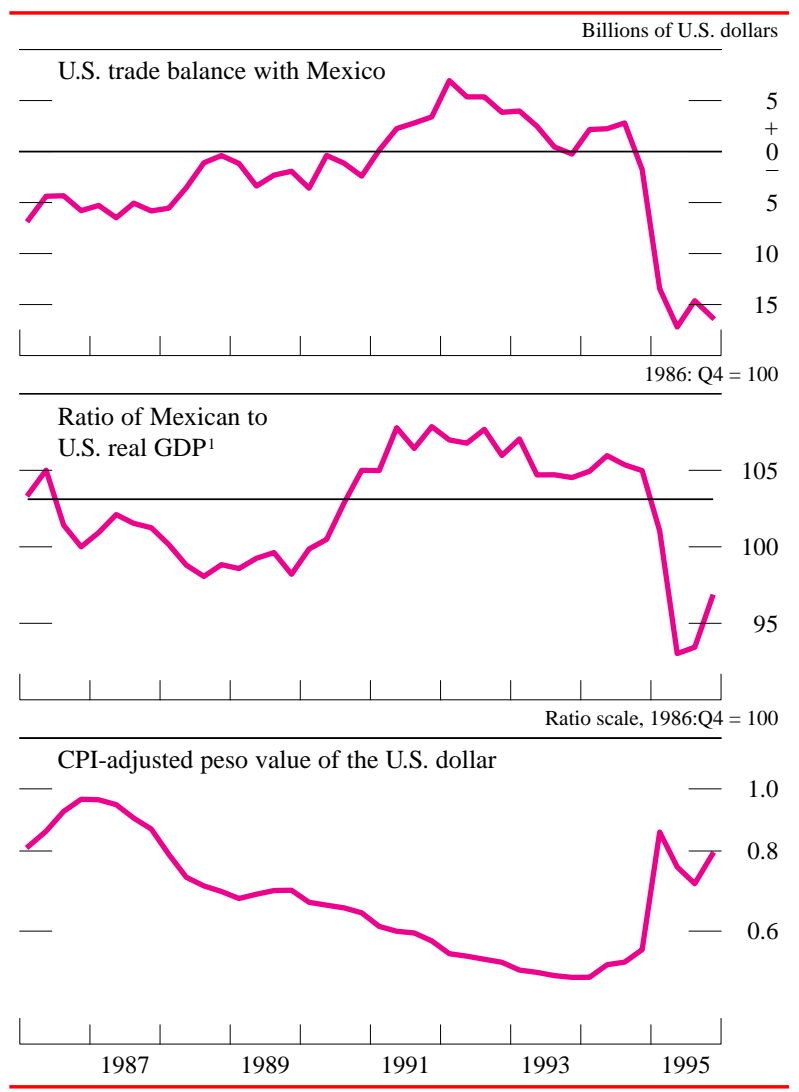

NoTE. The data are quarterly.

1. The horizontal line is the long-term trend. 
The deterioration of the trade balance was due in part to the direct effects of the real depreciation of the peso relative to the dollar, which decreased the relative attractiveness of U.S exports to Mexico and may also have increased U.S. demand for less-expensive Mexican goods and services. Probably a more important factor in the decline, however, was a sharp contraction of Mexican aggregate demand resulting from efforts by the Mexican government to tighten monetary conditions, maintain wage restraint, and reduce government spending.

\section{Relative Rates of Economic Growth}

The relationship between the U.S. trade balance in goods and services and relative rates of economic growth in other countries is most evident when the balance is compared with deviations of the ratio of foreign GDP to U.S. GDP from its historical trend (chart 3, top and middle panels). The ratio's rising trend means that the output of foreign countries has grown faster, on average, than that of the United States. The trade balance has tended to be closely related to deviations from the trend because of close historical associations between U.S. exports and foreign GDP and between U.S. imports and U.S. GDP. Positive deviations from the trend (that is, ratios higher than the trend ratio) indicate that foreign economies are growing even faster relative to the U.S. economy than has been true on average, and, therefore, positive deviations are generally associated with U.S. trade balance surpluses. Similarly, negative deviations are usually associated with trade balance deficits, though they have a somewhat larger effect on net trade than do positive deviations of the same magnitude because U.S. imports are more responsive to changes in U.S. GDP than are U.S. exports to changes in foreign GDP.

Although there have been periods (such as the 1980s) when swings in relative prices were a more important determinant of the trade balance than relative economic growth, more recently, movements in U.S. price competitiveness, as measured by the priceadjusted exchange value of the dollar (chart 3, bottom panel), have been quite modest and the trade balance has tended to move more in line with relative rates of GDP growth. In 1995, the economies of the United States and its major trading partners slowed markedly, to about the same rate of growth. Still, the trade balance deficit widened somewhat for the year as a whole, owing to the greater responsiveness of U.S. expenditures on imports to changes in domestic income compared with the responsiveness of foreign
3. Historical perspective on the U.S. trade balance and its proximate determinants, 1973-95

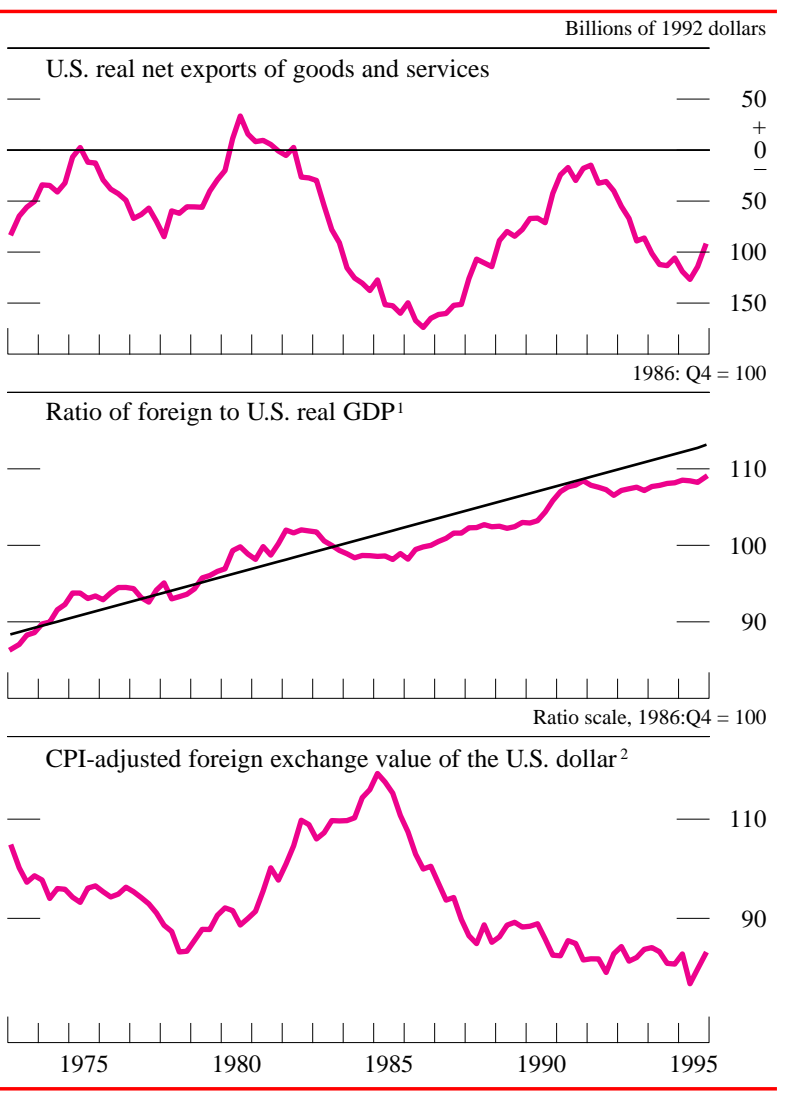

Note. The data are quarterly.

1. Foreign GDP is a weighted average of the GDPs of the foreign G-10 countries; see notes to table 2 for details. The straight line is the long-term trend.

2. The index is based on the foreign G-10 countries-Belgium-Luxembourg, Canada, France, Germany, Italy, Japan, the Netherlands, Sweden, Switzerland, and the United Kingdom- and eight developing countries-Brazil, Hong Kong, Korea, Malaysia, Mexico, the Philippines, Singapore, and Taiwan.

expenditures on U.S. exports to changes in foreign income.

The U.S. economy slowed to a $1 \frac{1 / 4}{4}$ percent rate of expansion in 1995 after growing at a $3 \frac{1}{2} 2$ percent rate in 1994 (table 2). The slower growth was due partly to efforts by businesses to reduce the pace of inventory accumulation after a burst of stockpiling in 1994. Final sales also slowed last year, as the growth of expenditures by both households and businesses slowed from elevated rates of increase in 1994. Although the growth of real expenditures on imported goods and services slowed, to a $4 \frac{1 / 4}{4}$ percent rate in 1995 from $11 \frac{1}{2}$ percent in 1994, imports continued to expand more rapidly than the pace of overall domestic spending.

The growth of real GDP in major foreign industrial countries other than Japan slowed sharply in 1995 from the robust rates of 1994. In Canada, where 
economic activity had been particularly vigorous through the end of 1994, the slowdown reflected weaker U.S. growth and Canadian macroeconomic policies directed toward improving the fiscal balance and preventing the reemergence of inflationary pressures. In Germany and the other European economies, appreciation of their currencies relative to the U.S. dollar in 1994 and in early 1995 and efforts to reduce public sector deficits contributed to the decline in the rate of real output growth. Japan, in contrast, showed some tentative signs of recovery late in 1995 after almost no growth during the previous three years.

Economic growth in the major developing countries also slowed on average in 1995 from the strong pace of 1994. The substantial contraction of economic activity in Mexico had important effects on U.S. trade, as noted earlier, but real output also slowed in other developing countries, including Argentina. The economies of the newly industrialized Asian countries-Malaysia, Korea, and Taiwan, for example-continued to grow rapidly in 1995, at about the same rate as in 1994. Although growth in most of these countries was driven by a strong expansion of internal demand, especially for investment, most countries also benefited from very fast export growth. The marked acceleration of exports was due at least in part to a real depreciation of those countries' currencies against the yen and key European currencies early in the year.

2. Growth of real GDP in the United States and selected foreign economies, 1993-95

Percent change, fourth quarter to fourth quarter

\begin{tabular}{|c|c|c|c|}
\hline Country & 1993 & 1994 & $1995^{1}$ \\
\hline United States & 2.2 & 3.5 & 1.2 \\
\hline Total foreign ....... & 2.8 & 4.5 & 2.0 \\
\hline Industrial countries 2 & 1.8 & 3.9 & 1.4 \\
\hline Canada...$\ldots \ldots$ & 3.1 & 5.4 & .6 \\
\hline Western Europe .......... & 6 & 3.7 & 1.6 \\
\hline Japan $\ldots \ldots \ldots \ldots \ldots \ldots$ & -.5 & .4 & 2.2 \\
\hline Developing countries $^{3} \ldots$ & 5.2 & 6.0 & 3.4 \\
\hline Asia $\ldots \ldots \ldots \ldots \ldots \ldots$ & 7.8 & 8.0 & 7.5 \\
\hline Latin America $\ldots \ldots \ldots$ & 1.9 & 3.4 & -1.6 \\
\hline Mexico $\ldots \ldots \ldots \ldots \ldots$ & .8 & 4.0 & -6.6 \\
\hline Other Latin America ...... & 2.9 & 2.9 & 3.0 \\
\hline
\end{tabular}

NotE. Aggregate measures are weighted by bilateral shares in U.S. nonagricultural merchandise exports in 1987-89.

1. Data for 1995 are partly estimated.

2. The industrial countries index includes Australia and New Zealand in addition to Canada, Japan, and Western Europe. The index for Western Europe comprises Belgium, France, Germany, Italy, the Netherlands, Sweden, Switzerland, the United Kingdom, Austria, Denmark, Finland, Greece, Ireland, Norway, Portugal, Spain, and Turkey.

3. The developing countries in the index for Asia are the Peoples Republic of China, Hong Kong, Korea, Malaysia, Mexico, the Philippines, Singapore, and Taiwan. The countries in "Other Latin America" are Argentina, Brazil, Chile, and Venezuela.

SOURCE. Various national sources.

\section{U.S. Price Competitiveness}

U.S. external performance is also influenced by the price competitiveness of those U.S. goods and services that compete against foreign imports in domestic markets and against other goods and services in foreign markets. U.S. goods and services gained some ground in domestic markets last year: The relative price of imported goods rose slightly, as price increases for imported goods just outpaced price increases for domestic goods (chart 4). U.S. exports have also become more competitive in world markets in recent years. Higher prices for foreign goods and services (especially in developing countries) relative to the prices of U.S. exports were the primary contributor to this development, though the significant depreciation of the foreign exchange value of the dollar in 1994 and 1995 also played a part.

\section{DEVELOPMENTS IN TRADE IN GOODS AND SERVICES}

Although the values of both exported and imported goods and services increased markedly last year, the value of imports rose somewhat more, causing the deficit in goods and services to widen slightly. In quantity terms, however, the rates of growth of both exports and imports slowed, in line with the slowing of the U.S. and foreign economies. (See the box for a discussion of the effects of using chain-type measures on the measurement of trade quantities as well as prices.)

4. Relative prices of exports and imports, 1987-95

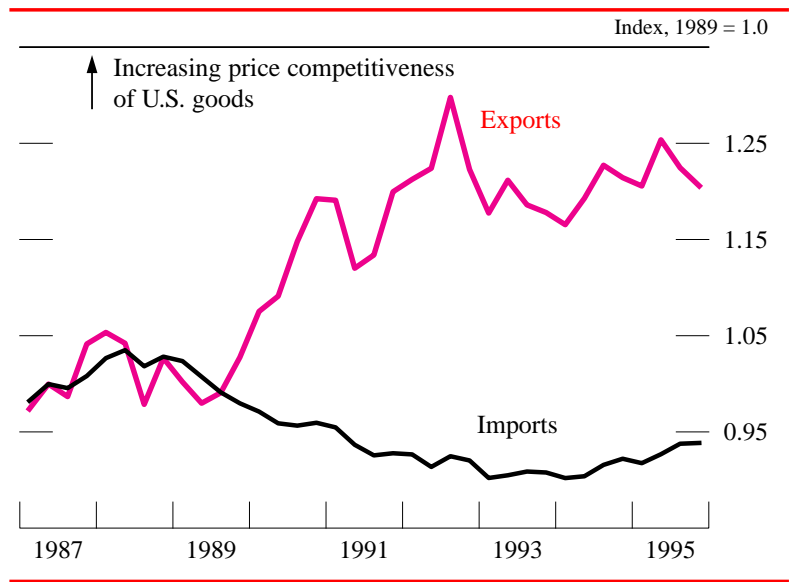

NotE. For exports, the index is the ratio of foreign prices to U.S. export prices of nonagricultural products, excluding computers. For imports, the index is the ratio of U.S. import prices of non-oil imports, excluding computers, to the U.S. GDP deflator. The data are quarterly. 


\section{Chain-Type Measures of U.S. Trade}

In 1995, the U.S. Department of Commerce's Bureau of Economic Analysis began computing quantity and price indexes for the various categories of U.S trade and for other measures of U.S. economic activity on a chain-type basis. Previously, quantity measures were calculated on a constant-dollar basis and price indexes on a fixed-weight basis (specifically, as price deflators). The old measures did not allow for the effects of changes in relative prices or changes in the composition of goods and services over time. In contrast, chain-type measures are calculated using weights that shift over time, with weights for a particular time period based on prices and quantities in adjacent years.

Although the move to chain-type measures had some quantitative effects on the measurement of trade movements, it changed the qualitative nature of these data very little. For the past several years, changes in quantities of

\section{Change in Trade Prices}

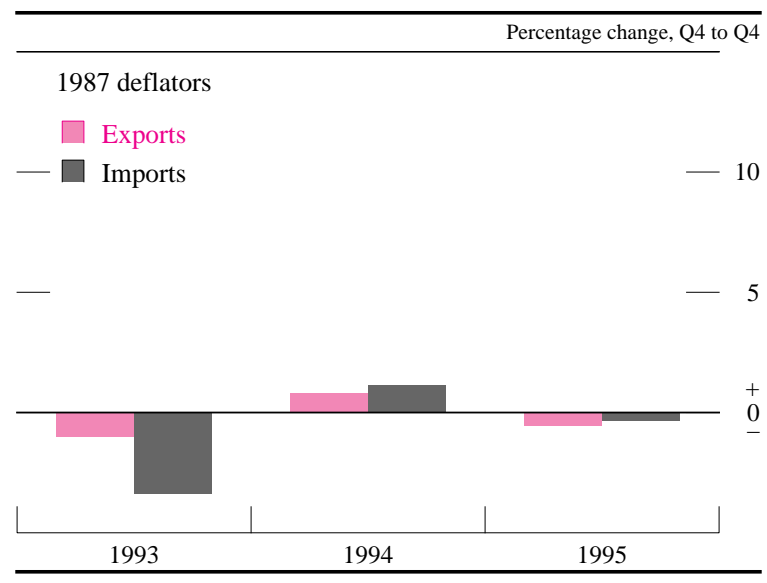

\section{Change in Trade Quantities}

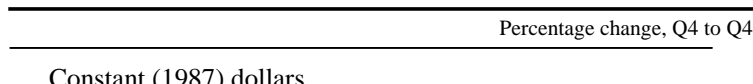

Constant (1987) dollars

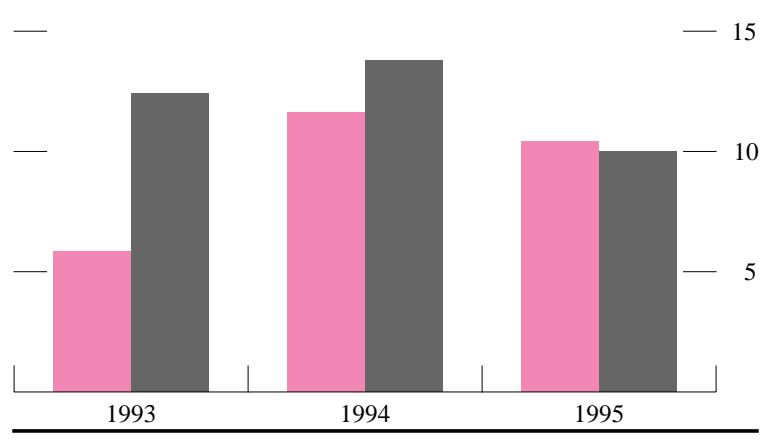

exports and imports, when calculated on a constant (1987) dollar basis, were by far the most important factor in the rise in the value of exports and imports and in the widening of the deficit in traded goods and services, whereas changes in prices of exports and imports played only a small role (chart, left panels). When calculated on a chain-type basis, changes in the prices of exports and imports show somewhat faster growth, although measured trade movements are still dominated by changes in quantities (chart, right panels). The more rapid rises in prices produced by the chain-type calculations are due mainly to a decrease in the weight assigned to computers, whose prices have fallen precipitously in recent years; in the chained (1992) dollar series, computers are given about half the weight they were given in the constant (1987) dollar series.
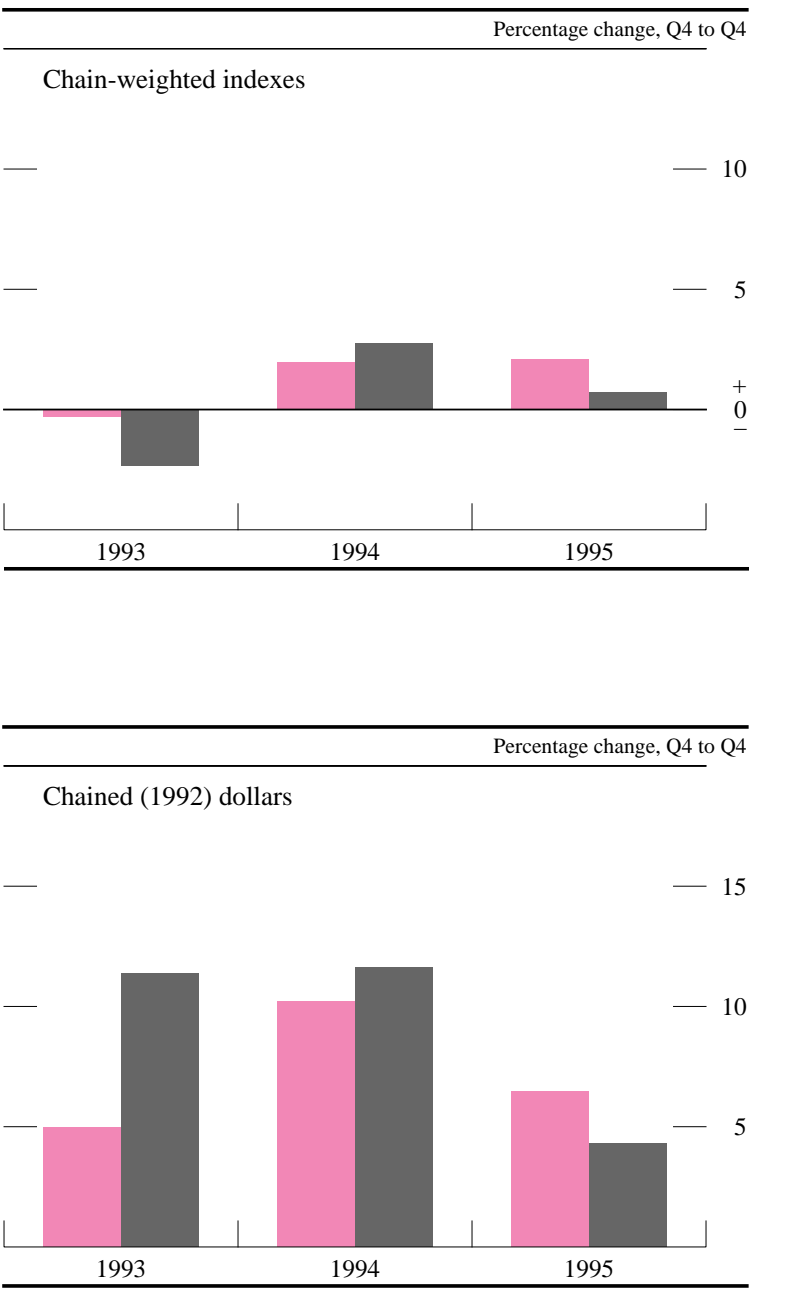
3. U.S. international trade in goods and services, 1993-95 Billions of dollars

\begin{tabular}{|c|c|c|c|}
\hline Item & 1993 & 1994 & 1995 \\
\hline Balance on goods and services . & -76 & -106 & -111 \\
\hline Exports of goods and services & 645 & 701 & 784 \\
\hline Services..$\ldots \ldots \ldots \ldots \ldots$ & 188 & 199 & 209 \\
\hline Goods ........... & 457 & 503 & 575 \\
\hline Agricultural & 44 & 47 & 57 \\
\hline Computers ........ & 29 & 33 & 40 \\
\hline Aircraft and parts & 33 & 31 & 26 \\
\hline Other capital ...... & 120 & 141 & 168 \\
\hline Consumer ............ & 55 & 60 & 64 \\
\hline Automotive products . & 52 & 58 & 61 \\
\hline Industrial supplies .... & 112 & 122 & 146 \\
\hline Other ............. & 12 & 11 & 13 \\
\hline Imports of goods and services & 719 & 807 & 895 \\
\hline Services ................... & 130 & 139 & 146 \\
\hline Goods ...................... & 589 & 669 & 749 \\
\hline Petroleum and products & 51 & 51 & 55 \\
\hline Computers ............. & 38 & 46 & 56 \\
\hline Other capital . & 114 & 138 & 166 \\
\hline Consumer .............. & 134 & 146 & 160 \\
\hline Automotive products & 102 & 118 & 124 \\
\hline Industrial supplies .... & 101 & 114 & 129 \\
\hline Foods and other ..... & 48 & 55 & 59 \\
\hline
\end{tabular}

SoURCE. U.S. Department of Commerce, Bureau of Economic Analysis, U.S. international transactions accounts.

\section{Robust Expansion of Exports}

The value of exported goods and services rose almost 12 percent last year, the fastest rate of increase since 1989 (table 3). Most of the increase was due to a rapid expansion of exported goods (especially capital goods and industrial supplies); exports of services advanced at a pace similar to that seen in recent years. Although the pace of economic activity slowed for many U.S. trading partners, demand for U.S. goods and services increased in most major regions of the world (table 4). The rate of growth of exports to industrial countries accelerated, with exports to Japan growing more than 20 percent and exports to

4. U.S. exports of goods to its major trading partners, 1993-95

Billions of dollars

\begin{tabular}{|c|c|c|c|c|}
\hline Importing region & 1993 & 1994 & 1995 & $\begin{array}{l}\text { Percent } \\
\text { change, } \\
\text { 1994-95 }\end{array}$ \\
\hline Total & 457 & 503 & 575 & 14 \\
\hline Industrial countries ${ }^{1}$ & 268 & 293 & 335 & 14 \\
\hline Canada ........... & 101 & 115 & 128 & 11 \\
\hline Western Europe .. & 111 & 115 & 132 & 15 \\
\hline Japan ................. & 47 & 52 & 63 & 21 \\
\hline Developing countries ${ }^{2}$ & 188 & 209 & 240 & 15 \\
\hline Asia $\ldots \ldots \ldots \ldots$ & 96 & 104 & 130 & 25 \\
\hline Latin America & 78 & 92 & 96 & 4 \\
\hline Mexico $\ldots \ldots \ldots \ldots$ & 42 & 51 & 46 & -10 \\
\hline Other Latin America .... & 37 & 41 & 50 & 22 \\
\hline
\end{tabular}

1. See note 2 to table 2 .

2. See note 3 to table 2 .

SoURCE. U.S. Department of Commerce, Bureau of Economic Analysis, U.S. international transactions accounts.
Western Europe rebounding to a 15 percent rate of expansion. Exports to developing countries in Asia and in Latin America (other than Mexico) were also very robust. In contrast, exports to Mexico contracted 10 percent, following a 21 percent increase in 1994.

Almost half the increase in export value came from rapid growth in the price of goods and services, as export prices were pushed up somewhat faster than in recent years. Growth in the quantity of exports (measured in chained (1992) dollars) picked up as the year progressed and totaled $6 \frac{1}{2}$ percent from the fourth quarter of 1994 to the fourth quarter of 1995 (table 5). The bulk of the 1995 increase was in exports of capital goods. High levels of investment spending in foreign countries, especially in Asia, led to a nearly 20 percent increase in exports of machinery. Machinery exports to Asian countries other than Japan advanced at a 30 percent rate, with Malaysia and other newly industrializing economies (especially Hong Kong, Korea, Singapore, and Taiwan) accounting for most of the increase. Shipments of machinery to Latin America were lackluster, primarily because shipments to Mexico contracted slightly. Exports of computers and semiconductors accounted for nearly two-thirds of the increase in machinery exports, with the rest of the increase in a wide range of other machines. The growth of capital goods exports was held back only slightly by a further decline in aircraft exports.

Exports of goods and services other than capital goods, which accounted for about two-thirds of exports last year, grew more slowly as a result of the slower pace of consumption spending in industrialized countries. Exports of consumer goods grew only 2 percent, down from a double-digit rate of growth in 1994. Canada, Japan, and Asia (mostly Hong Kong and Korea) each accounted for about one-fourth of the increase in exported consumer goods; exports to Mexico declined more than 15 percent. Automotive

5. Change in the quantity of U.S. exports, 1993-95 Percent change, fourth quarter to fourth quarter

\begin{tabular}{|c|c|c|c|}
\hline Type of export & 1993 & 1994 & 1995 \\
\hline All exports $\ldots \ldots \ldots \ldots$ & 5.0 & 10.2 & 6.5 \\
\hline Services & 4.7 & 5.4 & 3.3 \\
\hline Goods ......... & 5.1 & 12.3 & 7.7 \\
\hline Agricultural . & -5.7 & 18.0 & -2.9 \\
\hline Computers .. & 22.9 & 28.5 & 49.0 \\
\hline Aircraft and parts $\ldots \ldots \ldots$ & -9.8 & -16.9 & -16.7 \\
\hline Other capital ............ & 14.1 & 22.2 & 16.8 \\
\hline Consumer $\ldots \ldots \ldots \ldots$ & 4.9 & 13.0 & 2.1 \\
\hline Automotive products & 9.4 & 10.3 & -5.2 \\
\hline Industrial supplies ....... & .2 & 7.6 & 6.5 \\
\hline Other..$\ldots \ldots \ldots \ldots \ldots$ & -1.4 & 2.5 & 2.4 \\
\hline
\end{tabular}

Note. Quantities are measured in chained (1992) dollars. SourCE. U.S. Department of Commerce, Bureau of the Census. 
exports (including automotive parts to be assembled and shipped back to the United States) contracted at a 5 percent rate, owing to a slowdown in the U.S. and world auto markets. Notably, exports of automotive products to Japan jumped nearly a third, although the initial level of exports to Japan was relatively low. Exports of automotive products to Mexico contracted sharply.

Agricultural exports remained at an elevated level following a large jump in late 1994. Bountiful U.S. harvests in 1994 and robust world demand in 1995 (especially from Asia) resulted in vigorous shipments throughout much of the year, although exports faltered somewhat in the second half of the year following lower-than-expected 1995 harvests in the United States. The quantity of exported industrial supplies other than agricultural products grew $61 / 2$ percent last year, about the same pace as in 1994. Exports of services slowed to a 3 percent rate of expansion, likely because of the slowdown in economic activity in industrial countries.

\section{Rapid Growth of Imports}

The value of imported goods and services rose rapidly last year, only somewhat more slowly than in 1994. A significant portion of the increase was due to a $\$ 12$ billion surge in imports from Mexico. More than half the increase in the total value of imports was due to higher prices. The quantity of imports rose $4 \frac{1}{4}$ percent in 1995 , considerably more slowly than the double-digit rates of growth in 1993 and 1994 (table 6). The slowdown reflected slower U.S. economic growth and, to a lesser extent, somewhat higher import prices relative to the prices of domestic goods.

The sharpest increase was in the quantity of imported capital goods, which grew about 20 percent in 1995 compared with 30 percent in 1994.

6. Change in the quantity of U.S. imports, 1993-95 Percent change, fourth quarter to fourth quarter

\begin{tabular}{|c|c|c|c|}
\hline Type of import & 1993 & 1994 & 1995 \\
\hline All imports & 11.4 & 11.6 & 4.3 \\
\hline Services & 8.7 & .0 & 5.1 \\
\hline Goods $\ldots \ldots \ldots \ldots \ldots \ldots$ & 12.0 & 14.2 & 4.2 \\
\hline Petroleum and products & 10.0 & -.2 & -.3 \\
\hline Computers ............. & 40.0 & 36.9 & 42.3 \\
\hline 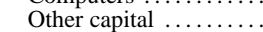 & 14.1 & 19.0 & 11.5 \\
\hline Consumer .......... & 8.5 & 11.2 & .3 \\
\hline Automotive products & 9.2 & 15.8 & -11.8 \\
\hline Industrial supplies ..... & 11.7 & 14.7 & -1.0 \\
\hline Foods and other ........ & 6.6 & 4.4 & 3.5 \\
\hline
\end{tabular}

Note. Quantities are measured in chained (1992) dollars.

Source. U.S. Department of Commerce, Bureau of the Census.
Imports of computers continued to expand rapidly, and imports of capital goods other than computerssemiconductors and industrial and service machinery, for example—also posted sharp gains.

Imports of goods other than capital goods grew much more slowly in 1995 than did imports of capital goods. Imports of consumer goods grew less than 1 percent, the slowest rate of increase since 1992, because of slowing imports of consumer durable goods. Imports of consumer goods from Mexico and China accounted for much of the increase, while imports from Japan were flat.

Automotive imports contracted last year for the first year since 1990, in line with the sharp slowdown in U.S. automobile sales. Imports of automotive products from Mexico remained strong, but imports from Canada were sluggish and imports from Japan contracted sharply. Imported quantities of industrial supplies were also weak, despite marked declines in the price of these products (especially metals).

\section{Oil Imports}

The value of oil imports rose more than 7 percent from 1994 to 1995 , as a $\$ 1.73$ per barrel (12 percent) increase in the average price of imported oil more than offset a nearly 4 percent decline in the volume imported. With the increase, the price returned to the midpoint of its post-Gulf War trading range from depressed levels in early 1994.

Changes in the prices of imported oil have tended to mirror changes in spot oil prices (West Texas intermediate) with a lag of several weeks (chart 5). Spot prices fell during the fourth quarter of 1994 and began 1995 near \$17 per barrel. The decline was

\section{Oil prices, 1983-95}

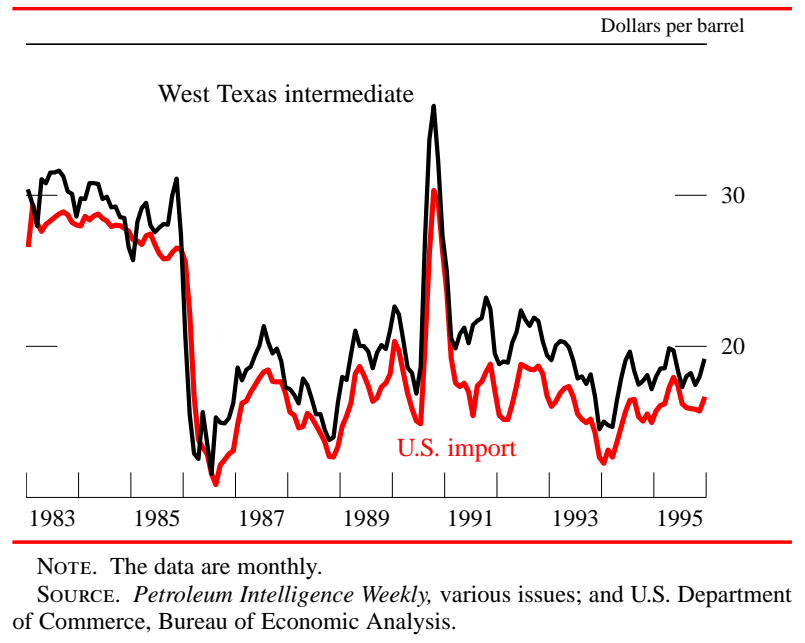


7. U.S. oil consumption, production, and imports, selected years, 1980-95 Millions of barrels per day

\begin{tabular}{|c|c|c|c|c|c|c|}
\hline Item & 1980 & 1985 & 1992 & 1993 & 1994 & $1995^{1}$ \\
\hline Consumption & 17.1 & 15.7 & 17.0 & 17.2 & 17.7 & 17.7 \\
\hline Production ... & 10.8 & 11.2 & 9.8 & 9.6 & 9.4 & 9.4 \\
\hline Imports $(\ldots, \ldots, \ldots, \ldots, \ldots, \ldots$ & 6.9 & 5.1 & 7.9 & 8.6 & 9.0 & 8.8 \\
\hline
\end{tabular}

due to a warmer-than-normal winter as well as to increases in non-OPEC oil production, especially in the North Sea. Two major factors temporarily increased prices during the year. The first was a protracted labor strike in Brazil, which trimmed roughly 600,000 barrels per day from non-OPEC oil production and led to price rises through May, to nearly $\$ 20$ per barrel. During the summer, prices declined, reflecting concerns about an overabundant supply on world oil markets. Then Gulf of Mexico hurricanes decreased October production roughly 600,000 barrels per day, and with colder-than-normal weather, prices rose to $\$ 19$ per barrel in December. Import prices mirrored these spot price changes and averaged $\$ 16.32$ per barrel in 1995, $\$ 1.73$ above the average for 1994.

The quantity of oil imports edged down from a rate of 9 million barrels per day in 1994 to 8.8 million barrels per day in 1995 (table 7). The decrease reflected a small drawdown of stocks; U.S. oil consumption and production changed little during the year.

\section{DEVELOPMENTS IN THE}

\section{NONTRADE CURRENT ACCOUNT}

The balance on investment income declined about $\$ 2$ billion last year, but the decline was more than offset by a temporary $\$ 6$ billion reduction in net

8. U.S. net investment income, 1992-95

Billions of dollars

\begin{tabular}{|c|c|c|c|c|}
\hline Item & 1992 & 1993 & 1994 & 1995 \\
\hline Investment income, net & 10 & 9 & -9 & -11 \\
\hline Portfolio investment income, net & -42 & -47 & -54 & -71 \\
\hline Receipts ...................... & 67 & 58 & 70 & 90 \\
\hline Private ........ & 59 & 53 & 66 & 86 \\
\hline Government & 7 & 5 & 4 & 5 \\
\hline Payments ..... & 108 & 105 & 124 & 161 \\
\hline Private .......... & 68 & 63 & 77 & 99 \\
\hline Government ............. & 41 & 42 & 47 & 61 \\
\hline Direct investment income, net & 52 & 56 & 45 & 59 \\
\hline Receipts ....................... & 52 & 62 & 68 & 91 \\
\hline Payments ....................... & 0 & 5 & 23 & 32 \\
\hline
\end{tabular}

SoURCE. U.S. Department of Commerce, Bureau of Economic Analysis, U.S. international transactions accounts. unilateral transfers abroad (table 1). The deterioration in net investment income was due entirely to a larger deficit in net portfolio investment income; net direct investment income increased.

\section{Net Portfolio Investment Income}

The balance on portfolio income registered a deficit of $\$ 71$ billion last year, significantly larger than the $\$ 54$ billion deficit recorded in 1994 (table 8). The balance on portfolio income has been in deficit since 1985 (chart 6), and the size of the deficit has broadly mirrored the net portfolio investment position. The net portfolio position deteriorated further last year, accounting for somewhat less than half the increase in the deficit on portfolio income. The remainder of the increase was due to a rise in the effective rate of return on the net portfolio position, with rates of return on both portfolio assets and liabilities rising, reflecting higher short-term U.S. interest rates in late 1994 and early 1995 (chart 7).

\section{Net Direct Investment Income}

The balance on direct investment income rebounded last year, increasing nearly $\$ 14$ billion after declining $\$ 11$ billion in 1994 (table 8). The recovery was more than accounted for by a $\$ 23$ billion jump in receipts 6. Net portfolio investment: Position and income, 1971-95

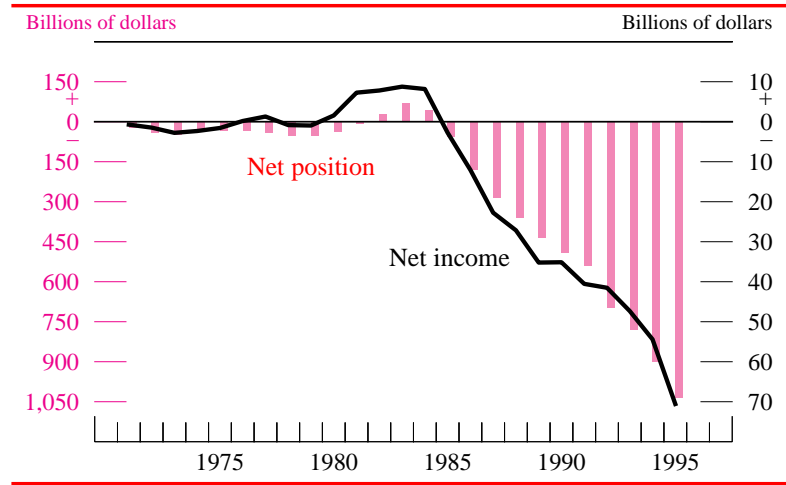

Note. The data are annual averages. The year-end position for 1995 was constructed by adding the recorded portfolio investment flows during 1995 to the recorded year-end position for 1994.

Source. U.S. Department of Commerce, Bureau of Economic Analysis; and the Federal Reserve Board. 
7. Rates of return on portfolio investment, 1986-95

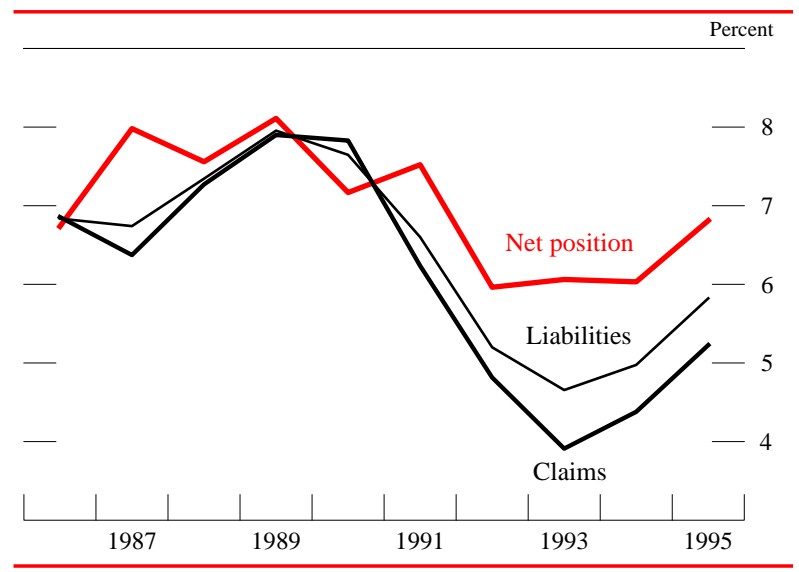

Note. For the net position, the data are the ratio of net investment income (receipts minus payments) to net position (claims minus liabilities). For claims (or liabilities), the data are the ratio of total receipts (or payments) to claims (or liabilities).

SourCE. U.S. Department of Commerce, Bureau of Economic Analysis; and the Federal Reserve Board.

on U.S. direct investment abroad. Receipts have tended to fluctuate somewhat with cycles of foreign economic activity and with changes in exchange rates, but they have generally increased with the growth of the U.S. direct investment position abroad (chart 8). The bulk of the improvement in receipts was due to a higher rate of return on U.S. direct investment (table 9), although receipts also benefited from an increase in the level of U.S. direct investment abroad.

Payments on foreign direct investment in the United States also increased in 1995, from \$23 bil-

\section{Direct investment: Position and income, 1977-95}

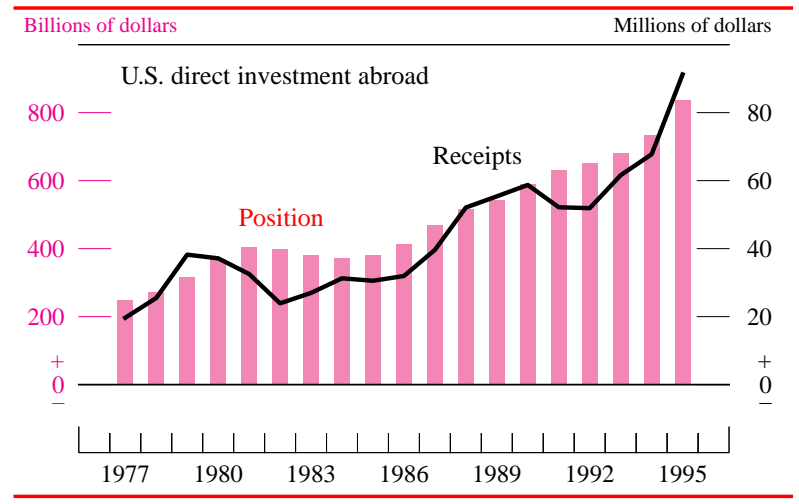

Note. The position data are period averages using the current-cost measures as of year-end for the current and previous years. The year-end data for 1995 were constructed by adding the recorded direct investment flows during 1995 to the recorded year-end position for 1994 . lion to $\$ 32$ billion, thus continuing the recovery from the very depressed levels recorded in the early 1990s. Such payments did not grow between 1988 and 1993, despite continued increases in the foreign direct investment position in the United States (chart 8). Although payments have been boosted in recent years by somewhat higher rates of return on the foreign direct investment position in the United Statesbringing the level of payments to record high levelsrates of return remain quite low and are well below their 1977-80 average (table 9).

\section{Unilateral Transfers}

Net unilateral transfers to foreigners-which include government grants and pension payments as well as net private transfers to foreigners-declined nearly $\$ 6$ billion last year, to $\$ 30$ billion (table 1). Most of the decrease was due to a temporary drop in government grants to foreign countries: Because of U.S. government shutdowns, government grants that were scheduled to be paid in the fourth quarter of 1995 were delayed until the beginning of 1996.

\section{CAPITAL ACCOUNT TRANSACTIONS}

The large U.S. current account deficit in 1995 was balanced by a large recorded net capital inflow and by a positive statistical discrepancy in the international transactions accounts, which comprises both unrecorded net capital inflows and unrecorded current account transactions (table 10). Most of the large recorded capital inflow was due to a record $\$ 110$ billion increase in foreign official holdings in the United

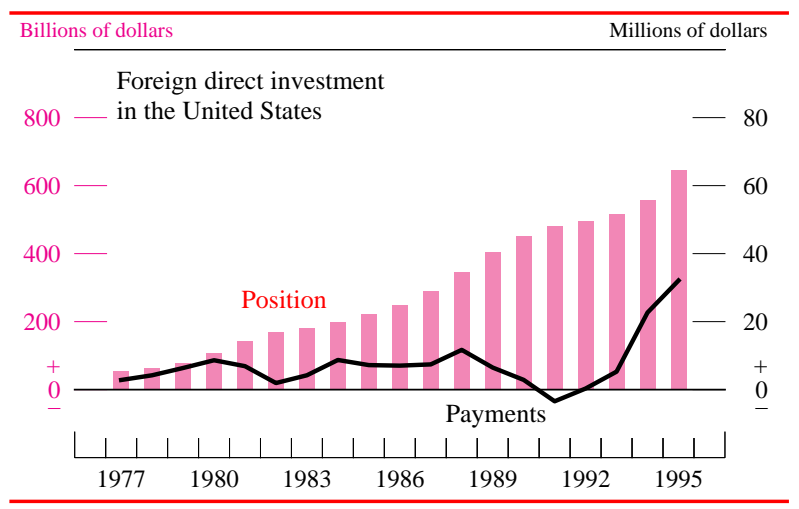

Source. U.S. Department of Commerce, Bureau of Economic Analysis; and the Federal Reserve Board. 
9. Rates of return on direct investment, 1977-95

Percent

\begin{tabular}{|c|c|c|c|c|c|c|c|c|c|}
\hline Item & $1977-80$ & $1981-88$ & 1989 & 1990 & 1991 & 1992 & 1993 & 1994 & $1995^{1}$ \\
\hline 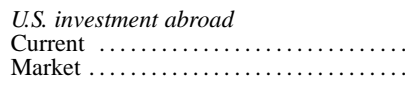 & $\begin{array}{l}9.9 \\
\text { n.a. }\end{array}$ & $\begin{array}{l}8.0 \\
\text { n.a. }\end{array}$ & $\begin{array}{r}10.2 \\
7.3\end{array}$ & $\begin{array}{r}10.0 \\
7.5\end{array}$ & $\begin{array}{l}8.3 \\
6.7\end{array}$ & $\begin{array}{l}8.0 \\
6.4\end{array}$ & $\begin{array}{l}9.0 \\
6.8\end{array}$ & $\begin{array}{l}9.2 \\
6.5\end{array}$ & $\begin{array}{r}11.3 \\
8.3\end{array}$ \\
\hline $\begin{array}{l}\text { Foreign investment in the United States } \\
\text { Current } \ldots \ldots \ldots \ldots \ldots \ldots \ldots \ldots \ldots \ldots \\
\text { Market } \ldots \ldots \ldots \ldots \ldots \ldots \ldots \ldots \ldots \ldots \ldots\end{array}$ & $\begin{array}{l}7.0 \\
\text { n.a. }\end{array}$ & $\begin{array}{l}3.1 \\
\text { n.a. }\end{array}$ & $\begin{array}{l}1.6 \\
1.4\end{array}$ & $\begin{array}{l}.6 \\
.5\end{array}$ & $\begin{array}{l}-.7 \\
-.6\end{array}$ & $\begin{array}{l}.1 \\
.1\end{array}$ & $\begin{array}{r}1.0 \\
.7\end{array}$ & $\begin{array}{l}4.1 \\
3.0\end{array}$ & $\begin{array}{l}5.2 \\
4.0\end{array}$ \\
\hline
\end{tabular}
direct investment for the current and previous years.

1. The year-end values of claims and liabilities that appear in the denominators are estimates constructed by adding the recorded direct investment flows during 1995 to the recorded year-end positions for 1994 .

States, reflecting both intervention on the part of certain industrial countries to support the foreign exchange value of the dollar and substantial reserve accumulation by several developing countries in Asia and Latin America.

Net purchases of U.S. securities by private foreigners were also quite large in 1995, reflecting the continued trend toward internationalization of securities markets. Net purchases of U.S. Treasury securities by private foreigners amounted to $\$ 99$ billion, far exceeding net purchases in previous years. In 1995, as in 1994, much of the foreign activity in the U.S. Treasury securities markets was channeled through Caribbean financial centers, reflecting in part the activities of hedge funds. A large portion of the net purchases of Treasury securities from the Caribbean appears to have been financed by repurchase agreements, accounting for a large part of the capital outflows reported by banks and securities dealers. Net purchases of U.S. corporate and other bonds were also at record high levels, in part reflecting the intensive use of the Eurobond markets by U.S. corporations. Foreign net purchases of U.S. corporate stocks (excluding stock swaps associated with cross-border mergers) were well below previous peaks despite the rapid rise in U.S. stock prices in 1995, which has in the past tended to attract capital flows from abroad.

U.S. net purchases of foreign securities in 1995 rebounded strongly after a very weak first quarter. For the year as a whole, net purchases of stocks from Japan accounted for almost 40 percent of total U.S. purchases of foreign stocks. U.S. investors apparently

10. Composition of U.S. capital flows, 1991-95

Billions of dollars

\begin{tabular}{|c|c|c|c|c|c|c|}
\hline Item & 1991 & 1992 & 1993 & 1994 & 1995 & $\begin{array}{l}\text { Change, } \\
\text { 1994-95 }\end{array}$ \\
\hline Current account balance ..... & -7 & -62 & -100 & -151 & -153 & -2 \\
\hline Official capital, net $\ldots \ldots \ldots \ldots \ldots \ldots \ldots$ & 26 & 43 & 70 & 44 & 100 & 56 \\
\hline Foreign official assets in the United States & 17 & 41 & 72 & 39 & 110 & 71 \\
\hline U.S. official reserve assets ............... & 6 & 4 & -1 & 5 & -10 & -15 \\
\hline Other U.S. government assets ............. & 3 & $-2^{4}$ & $\begin{array}{r}-1 \\
0\end{array}$ & 0 & 0 & 0 \\
\hline Private capital, net $\ldots \ldots \ldots \ldots \ldots \ldots \ldots$ & 10 & 45 & -7 & 121 & 46 & -75 \\
\hline Net inflows reported by U.S. banking offices & 3 & 36 & 51 & 115 & -39 & -154 \\
\hline Securities transactions, net .................. & 9 & 17 & -38 & 43 & 100 & 57 \\
\hline Private foreign net purchases of U.S. securities & 56 & 64 & 104 & 93 & 194 & 101 \\
\hline Treasury securities ....................... & 19 & 37 & 24 & 34 & 99 & 65 \\
\hline Corporate and other bonds ${ }^{1}$. & 27 & 31 & 61 & 56 & 82 & 26 \\
\hline Corporate stocks $\ldots \ldots \ldots \ldots \ldots \ldots$ & 10 & -4 & 19 & 3 & 13 & 10 \\
\hline U.S. net purchases of foreign securities & -46 & -46 & -142 & -50 & -94 & -44 \\
\hline Stocks $\ldots \ldots \ldots \ldots \ldots \ldots \ldots \ldots$ & -32 & -31 & -61 & -43 & -47 & -4 \\
\hline Bonds $\ldots \ldots \ldots \ldots$ & -15 & -15 & -81 & -7 & -47 & -40 \\
\hline Direct investment, net $\ldots \ldots \ldots \ldots \ldots \ldots \ldots$ & -10 & -21 & $\begin{array}{l}-01 \\
-32\end{array}$ & 0 & -22 & -22 \\
\hline Foreign direct investment in the United States & 22 & 18 & 41 & 49 & 75 & 26 \\
\hline U.S. direct investment abroad ${ }^{1} \ldots \ldots \ldots \ldots \ldots$ & -32 & -39 & -73 & -49 & -97 & -48 \\
\hline 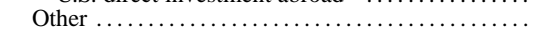 & 8 & 14 & 12 & -37 & 7 & 44 \\
\hline Statistical discrepancy & -29 & -26 & 36 & -14 & 7 & 21 \\
\hline
\end{tabular}

1. For 1991 and 1992, transactions with finance affiliates in the Netherlands Antilles are excluded from direct investment outflows and included in foreign purchases of U.S. securities. This adjustment was discontinued in 1993 on the assumption that by then virtually all the Eurobonds issued by Netherlands Antilles had come due.

SouRCE. U.S. Department of Commerce, Bureau of Economic Analysis, U.S international transactions accounts. 
had little interest in adding to their holdings of stocks or bonds from emerging markets in Latin America, in the wake of increased perceptions of risk resulting from the Mexican peso crisis.

Direct investment inflows reached $\$ 75$ billion in 1995, surpassing the previous record level, with mergers and acquisitions adding substantially to the inflow of funds from foreign direct investors in the United States. U.S. direct investment abroad, which totaled $\$ 97$ billion, was even larger than foreign direct investment in the United States and also surpassed previous peak levels. Mergers and acquisitions, as well as privatizations abroad, contributed to the outflow.

\section{PROSPECTS FOR 1996}

The U.S. external deficit in 1996 is expected to be near its 1995 level. A pickup in economic activity for our major trading partners should support expansion of exports of U.S. goods and services. Recent data also indicate that economic activity in the United States has picked up a bit in the early part of this year, suggesting a pace of import growth similar to that in 1995. Despite a small appreciation of the exchange value of the dollar in the first quarter, the United States appears to be holding on to its recent gains in international price competitiveness. Although the deficit in the balance on portfolio income is expected to grow larger this year, following a further deterioration in the net portfolio investment position, the increase is likely to be more than offset by an increase in net direct investment income, assuming that U.S. investors continue to earn high rates of return on their investments abroad similar to the rates earned in 1995. Net unilateral transfers to foreigners will be boosted in 1996 by those transfers that did not take place in the fourth quarter of last year. 